\title{
The Aconcagua River as another barrier to Liolaemus monticola (Sauria: Iguanidae) chromosomal races of central Chile
}

\author{
El río Aconcagua como otra barrera para las razas cromosómicas de Liolaemus \\ monticola (Sauria: Iguanidae) de Chile central
}

MADELEINE LAMBOROT, LAFAYETTE EATON \& BASILIO A. CARRASCO

Departamento de Ciencias Ecológicas, Facultad de Ciencias, Universidad de Chile, Casilla 653, Santiago, Chile; e-mail: mlamboro@codon.ciencias.uchile.cl

\begin{abstract}
Univariate and multivariate statistical analyses of 28 meristic characters recorded for 19 samples of the lizard Liolaemus monticola monticola were used to compare geographical variation in morphology with chromosomal races north and south of the Maipo River, and north and south of the Aconcagua River in central Chile, plus some affluent. This extends a previous morphological study that confirmed that the Maipo River is a biogeographical barrier that separates chromosomal races "Southern, $2 \mathrm{n}=34$ " and "Northern, $2 \mathrm{n}=38-40$ ", and reports for the first time the importance of the Aconcagua River as another biogeographical barrier between the chromosomal races "Northern, $2 \mathrm{n}=38-40$ " and the "Multiple Fission, 2n=42-44". The phenetic variation among samples is sufficient to differentiate the three chromosomal races, and also distinguishes populations within the chromosomal races such as the ones separated by the Colorado River, an affluent of the Aconcagua River. A possible historical sequence of events that accounts for the pattern of morphological differentiation is advanced.
\end{abstract}

Key words: chromosomal races, morphological variation, geographic barrier, Liolaemus monticola, Aconcagua River.

\section{RESUMEN}

Se emplearon análisis estadísticos univariados y multivariados de 28 caracteres merísticos de 19 poblaciones de Liolaemus monticola monticola para comparar la variación geográfica morfológica en las razas cromosómicas, tanto al sur y norte del río Maipo, como al sur y norte del río Aconcagua, más algunos afluentes. Este estudio es una extensión de trabajos previos que demuestran que el río Maipo constituye una barrera biogeográfica que separa las razas cromosómicas “Sur, 2 n=34” y "Norte, 2 n=38-40” y destaca por primera vez la importancia del río Aconcagua como otra barrera geográfica entre las razas cromosómicas "Norte, $2 \mathrm{n}=38-40$ " y "Múltiples Fisiones, 2n=42-44". La variación fenética entre las muestras es suficiente para diferenciar las tres razas cromosómicas, y también permite distinguir poblaciones dentro de cada raza, como por ejemplo las que separa el río Colorado, afluente del río Aconcagua. Proponemos una posible secuencia histórica de los eventos que darían cuenta de los patrones de diferenciación morfológica.

Palabras clave: razas cromosómicas, variación morfológica, barreras geográficas, Liolaemus monticola, río Aconcagua.

\section{INTRODUCTION}

Rivers may be barriers to dispersal, the most effective ones being those that change their courses least often (Mayr 1963). Riverine barriers sometimes separate races (Lamborot \& Eaton 1992, 1997) or closely related species (e.g., Haffer 1974); in other cases populations of the same race but conspicuously different in phenotype may be separated by a river. River size is generally a good predictor of differentiation (e.g., Pounds \& Jackson 1981), and the differences across a river are greater at its mouth than in the headwaters as in the Patton's "riverine barrier hypothesis"
(Patton et al. 1994). An opposite situation was found for the Liolaemus monticola chromosome races north and south the Maipo River in which historical aspects as Pleistocenic glaciations indicates that this river acted as a barrier more strongly near the headwaters of the river than near its mouth (Lamborot \& Eaton 1997). However, it is difficult to know if the rivers are facilitating differentiation or simply limiting the re-expansion of a former macrogeographic disjunct.

Liolaemus monticola (von Müller \& Helmich 1932 ) is a highly variable, endemic montane lizard species distributed along the temperate Andes, 
coastal and transversal ranges in Chile, between latitudes $30^{\circ}$ and $40^{\circ} \mathrm{S}$ at altitudes between 900 and 2,300 m (Donoso-Barros 1966, Peters \& Donoso-Barros 1970). This species displays a latitudinal gradient of karyotypic diversity (Lamborot 1993), and thus offers an ideal system for studying the possible evolutionary roles of various kinds of karyotypic modifications and modes of evolution in the differentiation of species. And because the dispersal of the L. monticola lizards is restricted by a number of rivers, it is possible to investigate the influence of several such barriers. Replicates of this sort are necessary for testing the hypothesis that differentiation is enhanced by intervening rivers.

At present we can distinguish several $L$. monticola monticola chromosomal races, whose chromosomal complexity increases from south to north: the "Primitive, $2 \mathrm{n}=32$ "; the "Southern, $2 \mathrm{n}=34$ "; the "Northern, $2 \mathrm{n}=38$ to 40 " and the "Multiple Fission, 2n=42 to 44" (Lamborot et al. 1979, 1981, Lamborot 1991, 1993, 1998, Lamborot \& Álvarez-Sarret 1993) plus others. The chromosomal differences in number and shape may be explained by centric fissions, pericentric inversions, translocation, increased chromosome size, and an increase in the microchromosome pairs.

The "Southern, $2 \mathrm{n}=34$ " and the "Northern, $2 \mathrm{n}=38-40 "$ chromosomal races are clearly separated by riverine barriers; in the Coastal Range by the Maipo River, and in the Andes by the Maipo River and one of its affluent, the Yeso River (Lamborot 1991, Lamborot \& Álvarez 1993). Hybridization between the races is found only in a narrow zone which was considered a zone of secondary contact, favored by man-made structures (Lamborot 1991). Multivariate analysis of meristic characters produced groups which coincided exactly with the separation of the chromosomal races, and thus confirmed the Maipo and the Yeso Rivers as river barriers (Lamborot \& Eaton 1992, 1997).

Chromosome analysis suggests that the Aconcagua River has also been a barrier to this species, presently separating the "Northern, $2 n=38-40$ " and the "Multiple Fission (MF), $2 n=42$ 44" chromosome races (Lamborot 1998, 2001).

Geological data for the region in Central Chile demonstrate that glaciation in the Pleistocene period was extensive (Brüggen 1950, Vuilleumier 1971, Caviedes 1972). The Aconcagua Valley $\left(32^{\circ} 50^{\prime} \mathrm{S}\right)$, located in the transition between the arid zone of the so-called "Norte Chico" and the temperate winter humid part of Middle Chile, has a history of glaciations similar to that of the Maipo River Valley. Thus if differentiation is enhanced by riverine barriers, we should expect the variability in the Aconcagua Valley to parallel that of the Maipo Valley.

In this contribution, we assess the degree of morphological divergence that has occurred within and between the two L. m. monticola chromosomal races "Northern, $2 \mathrm{n}=38-40$ " and "MF $2 \mathrm{n}=42-44$ " (Lamborot 1998). We compare these populations with some representative localities belonging to the "Southern, $2 \mathrm{n}=34$ " and the "Northern, $2 \mathrm{n}=38$ 40 " chromosomal races from the Andes and the Coastal Ranges. We test whether the derived "MF" differs in variability from the ancestral race, and the importance of the Aconcagua River as a barrier to the gene flow between races. Furthermore, we offer possible explanations for the present distribution of chromosomal races of $L . m$. monticola and the importance of the rivers as biogeographical barriers in the central Chile.

\section{MATERIALS AND METHODS}

Adults of three chromosomal races of Liolaemus monticola monticola were sampled from different localities north and south of the Aconcagua and the Maipo rivers and affluent (Fig. 1, Table 1). The "Multiple Fission, $2 n=42-44$ " race localities were the following: from the Coast Range, Cabrería (1-CAB), Mina El Soldado (2-SOLD), Mina Cerrillos (3-CERR), Mina Hierro Viejo (4-HVIE) and from the Andes: Río Rocín (5-ROC). The "Northern, $2 \mathrm{n}=38-40$ " race localities were the following: from the Andes, Saladillo (10-SAL), Río Colorado Sur (11-CSUR) and Río Colorado Norte (13-CNOR) plus the previously described localities Yeso Norte (9-YNOR) and San Gabriel (12-GAB), (Lamborot \& Eaton 1997) and from the Coastal Range: Cuesta la Dormida (6-DOR), Cerro El Roble (7-ROB) and a sample from Cuesta Chacabuco (8-CHAC) located in the Transversal Range between the coastal and the Andean ranges.

We also included samples of the "Southern, $2 \mathrm{n}=34$ " race localities (Lamborot \& Eaton 1997) from the Coastal Range, Cerro Cantillana (14CAN); from the Andes, Río Clarillo (18-CLAR), Volcán Sur (16-VSUR), Volcán Norte (17VNOR), Yeso Sur (19-YSUR) and Los Queñes (15-QUE), which is $200 \mathrm{~km}$ south of the other populations. The Yeso Sur population is located $200 \mathrm{~m}$ from Yeso Norte, and is connected by a bridge which crosses the Yeso River; a few interracial hybrid individuals (Lamborot 1991, Lamborot \& Eaton 1992) are included in the sample. Most individuals from each sample were karyotyped (Lamborot 1991, 1998, Lamborot \& 
Álvarez-Sarret 1993, M. Lamborot unpublished results).

Details of the localities and sample sizes are given in Table 1. Voucher specimens are deposited by individual catalogue numbers in the Laboratorio de Citogenética, Facultad de Ciencias, Universidad de Chile.

\section{Chromosomal data}

Standard karyotypes were obtained from bone marrow, liver, spleen and testes for a subset of specimens collected in each locality following the colchicine-hypotonic pretreated air-drying treatment (Evans et al. 1964), and stained with Giemsa and classified in accordance to a chromosomal race.

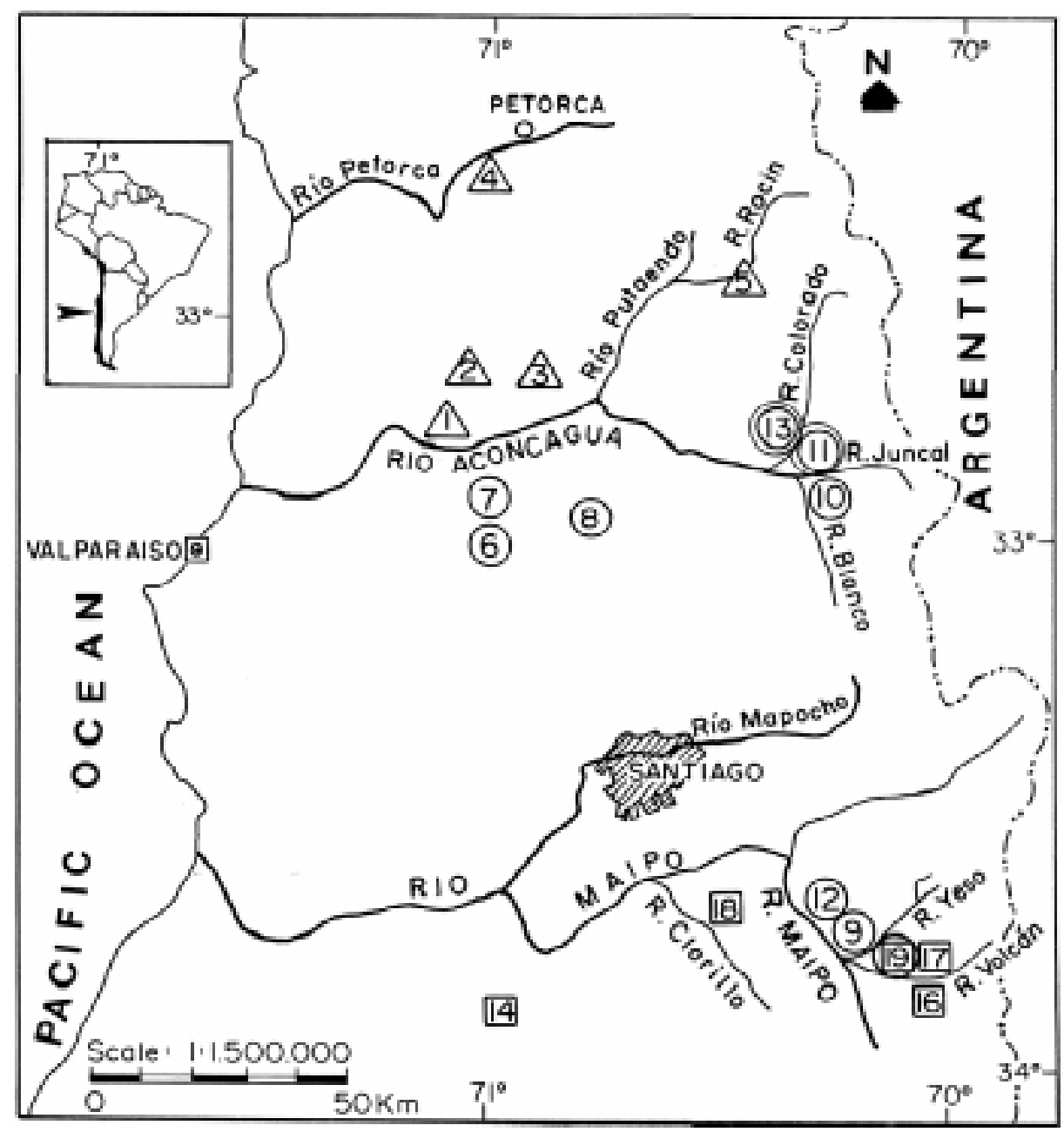

Fig. 1: Map of central Chile showing locations of 18 sampling sites of Liolaemus monticola (see Table 1) in the Andes, Coastal and Transversal ranges. Numbers enclosed in triangles represent sampling localities of the "Multiple Fission, 2n=42-44" race; those enclosed in circles represent sampling localities of the "Northern, 2n=38-40" race; those enclosed in double circles represent sampling localities of the "Northern modified 1, 2n=38-40" race, north and south the Colorado River, an affluent of the Aconcagua River; those enclosed in squares are localities of the "Southern, $2 \mathrm{n}=34$ " race; the circle and square together represents the zone of secondary contact. The sampling locality of Los Queñes (15) is not shown on the map; it is about $200 \mathrm{~km}$ south of the Maipo River.

Mapa de Chile central y ubicación de 18 sitios de muestreo de Liolaemus monticola (ver Table 1) en las cordilleras de Los Andes, de La Costa y Transversal. Los números dentro de los triángulos representan las muestras de las localidades de la raza "Múltiple Fisiones, 2n=42-44; aquellas enceradas en círculos representan las localidades de la raza "Norte 2n=38-40"; con doble círculo se representa las localidades de la raza "Norte modificada 1, 2n=38-40" al norte y al sur del río Colorado, afluente del río Aconcagua; aquellas encerradas en cuadrados corresponden a localidades de la raza "Sur, 2n=34"; el círculo y el cuadrado juntos representan la zona de contacto secundario. La localidad de Los Queñes (15) distante de unos $200 \mathrm{~km}$ al sur del río Maipo, no se muestra en el mapa. 
TABLE 1

Localities, chromosomal races and sample sizes of the Liolaemus monticola monticola populations used in this study. Sample numbers correspond to those of figures

Localidades, razas cromosómicas y tamaño de las muestras de las poblaciones de Liolaemus monticola monticola usadas en este estudio. Los números de las muestras corresponden a la de las figuras

\begin{tabular}{|c|c|c|c|c|c|c|c|c|c|}
\hline $\begin{array}{l}\text { Sample } \\
\text { numbers }\end{array}$ & \multicolumn{2}{|c|}{$\begin{array}{c}\text { Sample size } \\
\text { Males - Females }\end{array}$} & $\begin{array}{l}\text { Chromosomal } \\
\text { race }\end{array}$ & $2 n$ & Locality & Range & $\begin{array}{l}\text { Latitude } \\
\text { South }\end{array}$ & $\begin{array}{l}\text { Longitude } \\
\text { West }\end{array}$ & $\begin{array}{l}\text { Altitude } \\
\text { (m) }\end{array}$ \\
\hline 1 & 0 & 6 & MF & $42-44$ & Cabrería & Coast & $32^{\circ} 49^{\prime}$ & $71^{\circ} 05^{\prime}$ & 800 \\
\hline 2 & 12 & 9 & MF & $42-44$ & Mina El Soldado & Coast & $32^{\circ} 42^{\prime}$ & $71^{\circ} 04^{\prime}$ & 1,500 \\
\hline 3 & 4 & 8 & MF & $42-44$ & Mina Cerrillo & Coast & $32^{\circ} 42^{\prime}$ & $70^{\circ} 55^{\prime}$ & 1100 \\
\hline 4 & 21 & 13 & MF & $42-44$ & Mina Hierro Viejo & Coast & $32^{\circ} 17^{\prime}$ & $71^{\circ} 02^{\prime}$ & 1,350 \\
\hline 5 & 20 & 7 & MF & $42-44$ & Río Rocín & Andes & $32^{\circ} 28^{\prime}$ & $70^{\circ} 27^{\prime}$ & 1,500 \\
\hline 6 & 32 & 33 & Northern & $38-40$ & Cuesta La Dormida & Coast & $33^{\circ} 03^{\prime}$ & $71^{\circ} 02^{\prime}$ & $900-1,350$ \\
\hline 7 & 22 & 21 & Northern & $38-40$ & El Roble & Coast & $32^{\circ} 58^{\prime}$ & $71^{\circ} 01^{\prime}$ & $1,000-1,450$ \\
\hline 8 & 13 & 11 & Northern & $38-40$ & Cuesta Chacabuco & Transverse & $32^{\circ} 59^{\prime}$ & $70^{\circ} 44^{\prime}$ & 1,100 \\
\hline 9 & 16 & 14 & Northern & $38-40$ & Yeso Norte & Andes & $33^{\circ} 47^{\prime}$ & $70^{\circ} 12^{\prime}$ & 1,300 \\
\hline 10 & 18 & 18 & Northern & $38-40$ & Saladillo & Andes & $32^{\circ} 55^{\prime}$ & $70^{\circ} 18^{\prime}$ & 1,450 \\
\hline 11 & 18 & 17 & Northern & $38-40$ & Río Colorado Sur & Andes & $32^{\circ} 51^{\prime}$ & $70^{\circ} 23^{\prime}$ & 1,250 \\
\hline 12 & 11 & 11 & Northern & $38-40$ & San Gabriel & Andes & $33^{\circ} 46^{\prime}$ & $70^{\circ} 14^{\prime}$ & 1,230 \\
\hline 13 & 14 & 10 & Northern & $38-40$ & Río Colorado Norte & Andes & $32^{\circ} 50^{\prime}$ & $70^{\circ} 24^{\prime}$ & 1,250 \\
\hline 14 & 31 & 20 & Southern & 34 & Cantillana & Coast & $33^{\circ} 57^{\prime}$ & $70^{\circ} 56^{\prime}$ & $1,400-1,600$ \\
\hline 15 & 21 & 18 & Southern & 34 & Los Queñes & Andes & $35^{\circ} 37^{\prime}$ & $70^{\circ} 58^{\prime}$ & 1,450 \\
\hline 16 & 10 & 8 & Southern & 34 & Volcán Sur & Andes & $33^{\circ} 48^{\prime}$ & $70^{\circ} 09^{\prime}$ & 1,415 \\
\hline 17 & 13 & 10 & Southern & 34 & Volcán Norte & Andes & $33^{\circ} 48^{\prime}$ & $70^{\circ} 09^{\prime}$ & 1,420 \\
\hline 18 & 12 & 12 & Southern & 34 & Río Clarillo & Andes & $33^{\circ} 43^{\prime}$ & $70^{\circ} 30^{\prime}$ & 950 \\
\hline 19 & 12 & 10 & $\begin{array}{c}\text { Southern Northern } \\
\text { Hybrids }\end{array}$ & $\begin{array}{c}34 \\
36-37\end{array}$ & Yeso Sur & Andes & $33^{\circ} 47^{\prime}$ & $70^{\circ} 13^{\prime}$ & 1,300 \\
\hline
\end{tabular}

\section{Characters}

We scored 40 meristic scale characters on each individual. Many typical scale counts do not follow a normal distribution or are nearly invariant (Sites 1982, Lamborot \& Eaton 1992); we include here only those 28 characters which were variable and approximately normal. The characters used were the following: CORA or Supraorbital semicircle: number of circumorbital scales separating the enlarged supraocular from median head scales; CORB: number of circumorbital scales plus the scales between the superciliaries and supraorbital; SOR: all scales inside CORB, within the semicircle of circumorbital scales; SCI or superciliaries: row of enlarged scales lying in the border of the upper eyelid; TEM or temporal scales: number of scales between the posterior margin of the eye and the middle of the ear; SAP: number of scales bordering the parietal; POSPA: number of postparietals; FRON: frontal scale or number of scales in the area of the frontal scale; SAF: number of scales bordering the frontal(s); POSFR: number of postfrontal (s); LORA: scales in the loreal region between canthals, supralabials and subocular; LORB: LORA scales plus the supralabials; LASUP2A: row of scales over the first row of labials, from the rostral to the level of the posterior end of the enlarged subocular; LASUP2B: second row of scales from the rostral to the level of the labial commissure; LAINFA: number of enlarged infralabial scales behind the mental; AURS: number of enlarged scales protuding on the anterior edge of the right side ear opening; SARO: number of scales bordering the rostral; SANA: number of scales bordering the nasal; SBRF: number of scales in the middle way between the rostral and the frontal; GUS: row of scales across the gular region, between each anterior margin of the ear openings; DOS: number of scales in the vertebral line from the posterior margin of the head scales to the level of the genital ridge; VES: number of ventral scales from the posterior margin of the mental scale straight back to the base of the genital ridge; SAB: number of scales around the midbody; DORCA: number of mid-dorsal vertebral scales in a line equal to the length of the head; AVCO: number of scales around the 15 th verticile of the tail counted from the level of the genital ridge; LAMA: number of subdigital lamellae on the fourth toe of the right forelimb; LAPA; number of subdigital lamellae on the fourth toe of the right hindlimb; APOR: number of preanal pores (only in males). 
In previous analyses, asymmetry was tested by measuring scale characters on both sides of the body in four populations. Since we found no appreciable evidence for asymmetry (Lamborot \& Eaton 1992) we measured only the right side of the body for bilateral characters.

\section{Statistical analyses}

Statistical procedures included tests for normality (Kolmogorov-Smirnov D-Max, skewness and kurtosis), ANOVA and factor analysis (Sokal \& Sneath 1995). Factor scores from factor analysis were clustered by UPGMA (Sneath \& Sokal 1973).

Relative variability for characters of males was determined as previously described (Eaton 1971, Lamborot \& Eaton 1992). We also calculated the average of the coefficients of variation for purpose of comparison.

\section{RESULTS}

Although the means for most characters were not notably different among populations (Table 2), all 28 characters showed significant differences (analysis of variance, $\mathrm{P}<0.05$ ), which justifies their use in multivariate analysis. Previous morphological analyses demonstrated a certain degree of difference between characters means of males and females from the same population, however, the differences were small enough that the patterns revealed by factor analysis were not distorted by combining data (Lamborot \& Eaton 1992, 1997). We therefore combined the data of the females and males for most analyses to increase sample sizes. The number of anal pores (APOR) is the character which showed the greatest differences among populations (Table 2), this trait can only be scored in males. In order to include this character in the analyses which combined males and females, we used the mean of APOR in males as the "population" sample mean. However, there were no males in the sample from Cabrería (sample 1), thus it was necessary to exclude this locality from the analyses which used APOR. The affinities of Cabrería were determined in an analysis using only females (see below).

Factor analysis of 28 character means from 18 populations (Table 2, except for Cabrería)

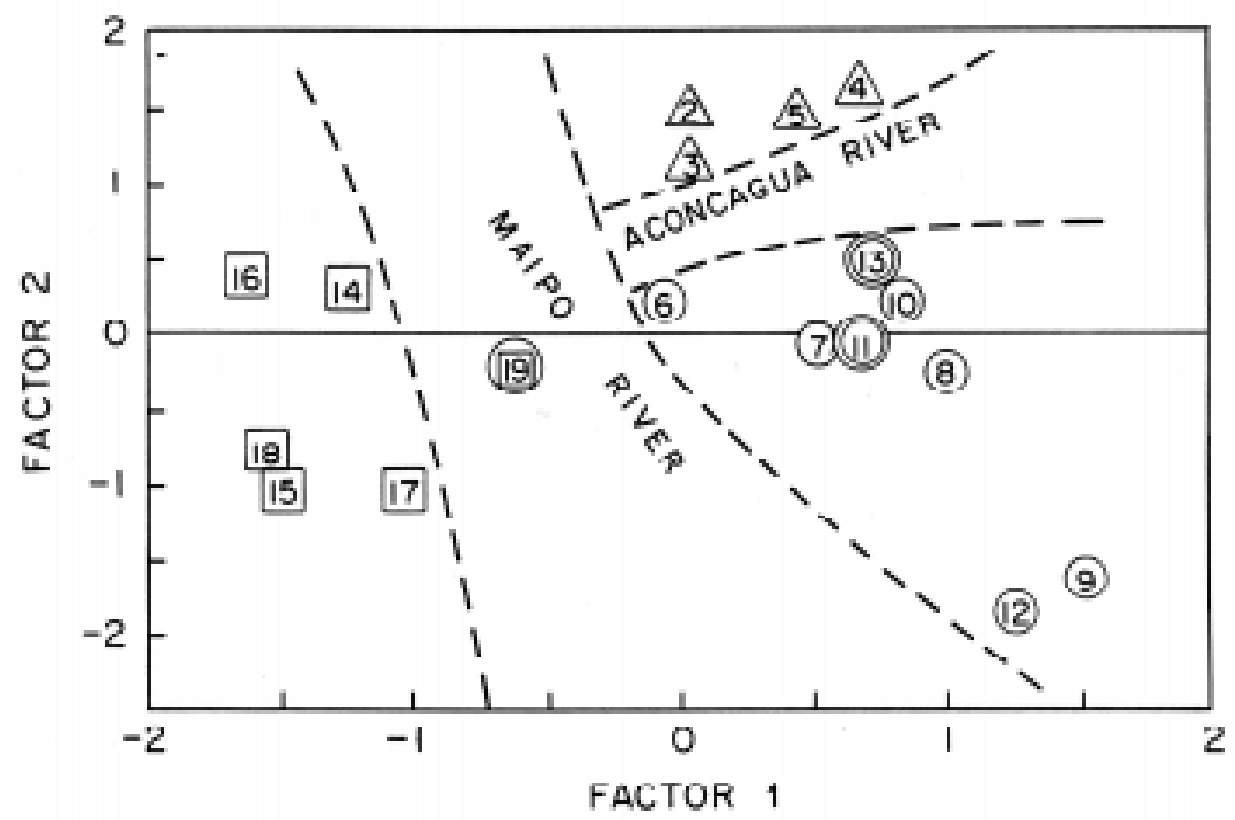

Fig. 2: Graph of the first two principal components produced using scale count characters of 18 populations of Liolaemus monticola males plus females from central Chile. Triangles represent the "Multiple Fission, 2n=42-44" race; circles represent the "Northern, $2 n=38-40$ " race; double circles represent a new "Northern modified 1 chromosome race"; squares are the "Southern chromosomal race".

Gráfico de los dos primeros componentes principales en base a caracteres merísticos de número de escamas en 18 poblaciones de machos y hembras de Liolaemus monticola en Chile central. Los triángulos representan la raza "Múltiple Fisiones, 2n=42-44"; los círculos representan la raza "Norte, 2n=38-40; el doble círculo representa una nueva raza cromosómica denominada "Norte modificada 1, 2n=38-40"; los cuadrados corresponden a la raza cromosómica "Sur, $2 \mathrm{n}=34 "$. 


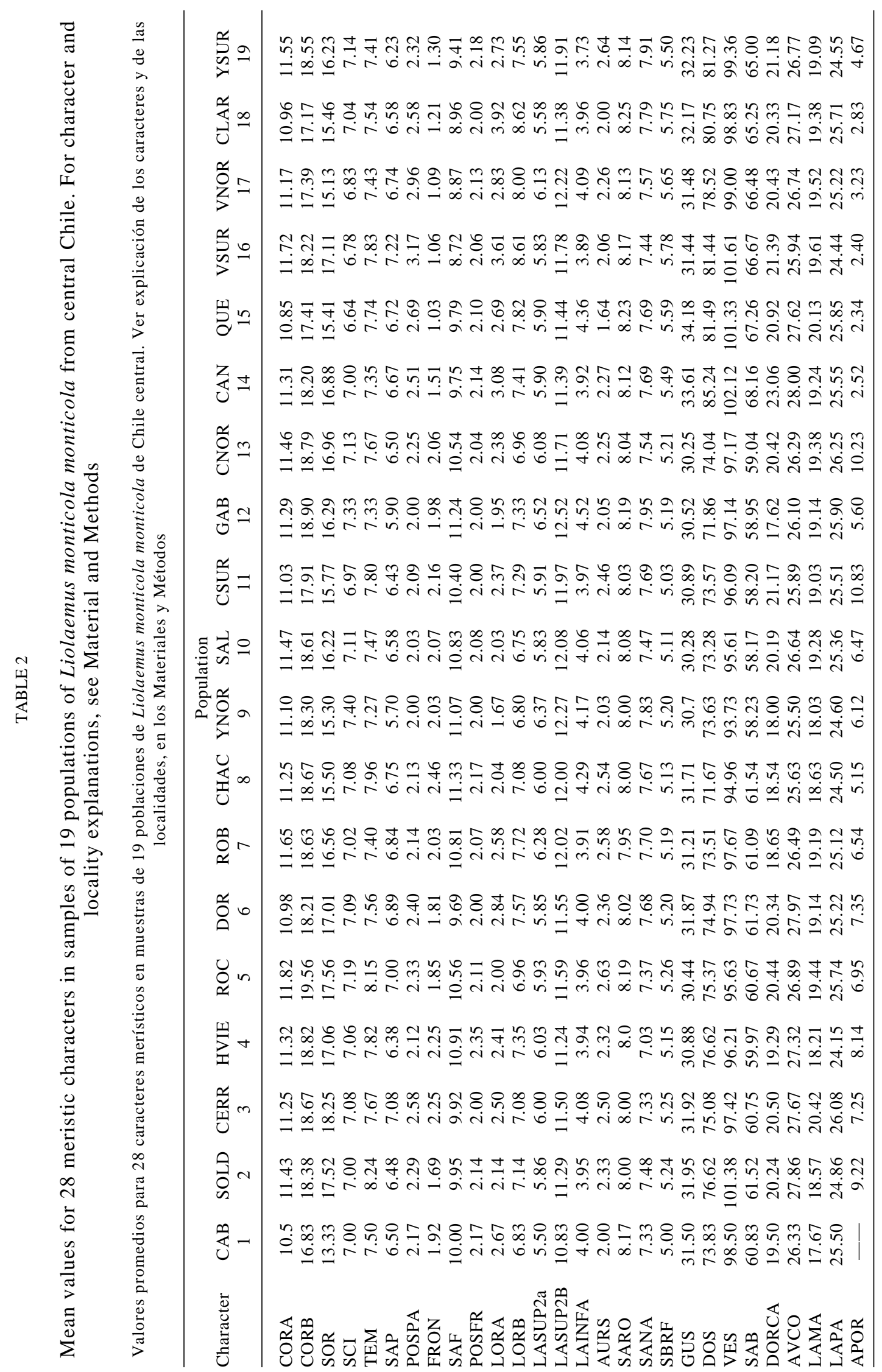


separated populations in agreement with chromosomal race and geographic location (Fig. 2). The first component, which accounts for nearly $39 \%$ of the total variation, has significant loadings for eleven (SCI, FRON and SAF, positive values and POSPA, LORA, LORB, SBRF, GUS, DOS, VES, SAP with negative values) of the 28 characters. The factor scores for this factor clearly separates the "Southern, $2 \mathrm{n}=34$ " race (scores less than -1) from the other chromosomal races (Fig. 2). The "Northern" race (scores greater than 0), except the Yeso Sur sample and Multiple Fission race. The sample (Yeso Sur 19) with hybrid individuals appears in an intermediate position (Fig. 2). The second component (17\%) had significant loading for two characters (SOR and SANA, positive and negative values) and accounted for about one sixth of the total variation. This factor separates populations of the "Multiple Fission, $2 n=42-44$ " race (scores greater than +1 ) from those of the other races (Fig. 2), and coincides with the position of the Aconcagua River (Fig. 1). A separate analysis was performed using only females, including the Cabrería sample 1 and using 27 characters (excluding APOR). The results were very similar to those of the entire samples, and Cabrería grouped with the other "MF" race populations (results not shown).

When the comparisons are between factor 2 and 3 that account for the 17 and $8.5 \%$ of the total variation, (Fig. 3) two characters: SOR (positive loading) and SANA (negative loading) are significative and clearly show that the Maipo and the Aconcagua rivers segregate the three chromosomal races and depicts the Colorado River samples one of the affluent of the Aconcagua River, may also be a barrier to gene flow. Interestingly, the greatest divergence in factor scores for the third factor have occurred within the different populations of the Multiple Fission race.

We computed Euclidean (Sokal \& Sneath 1995) distances for the first two or three factors, and used both UPGMA, and non-hierarchical clustering (Eaton 1971, Lamborot \& Eaton 1992) of the factor scores that grouped populations according to chromosome race (Fig. 3 and 4). The UPGMA dendrogram using the factor scores of

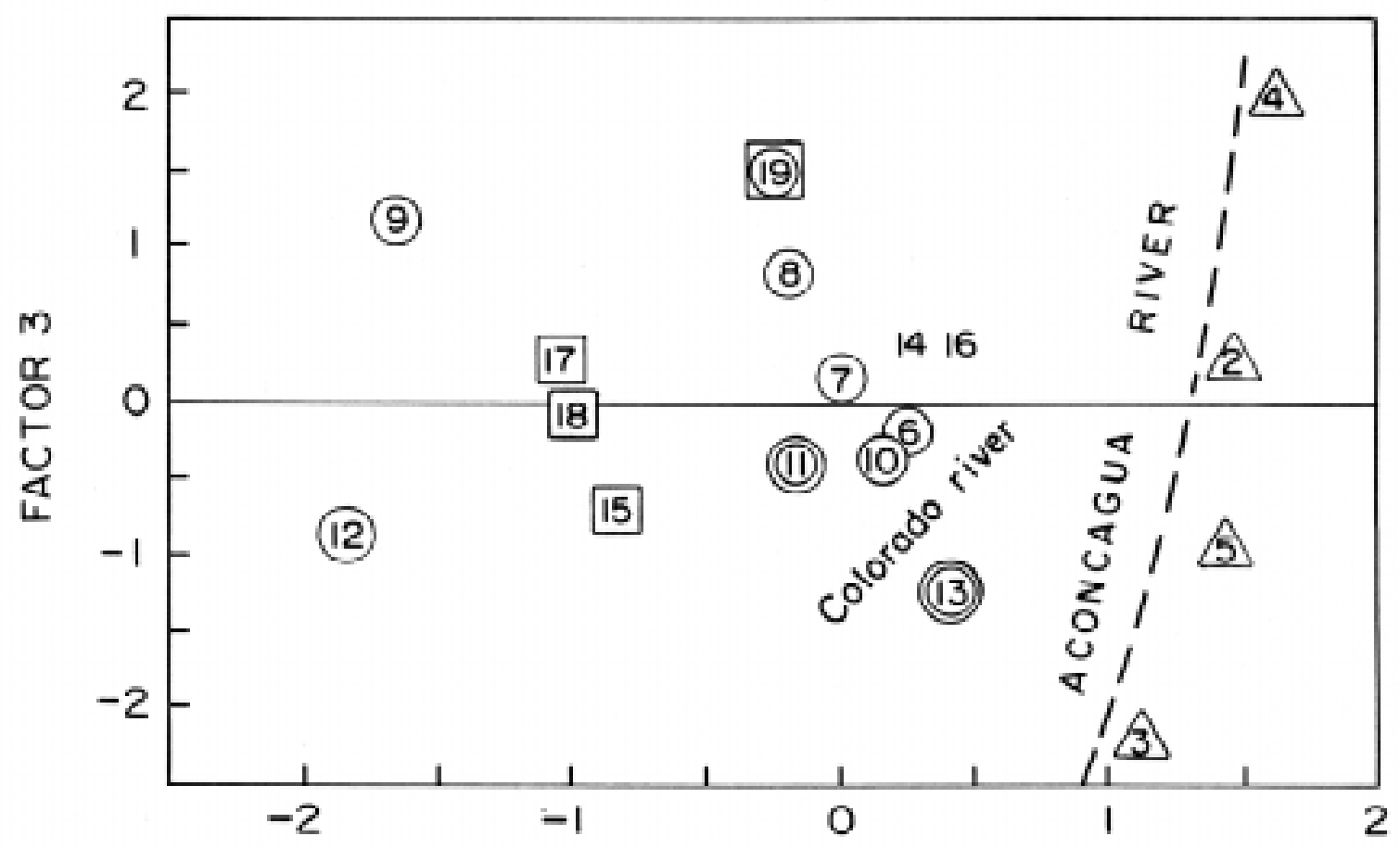

FACTOR 2

Fig. 3: Graph of the second and third principal components produced using 28 scale count characters of 18 populations of Liolaemus monticola from central Chile (sample Cabrería was excluded from the analysis). Numbers and symbols are those of Fig. 2.

Gráfico del segundo y tercer componente principal producido en base a 28 caracteres merísticos (conteo de escamas) en 18 poblaciones de Liolaemus monticola de Chile central (la muestra de Cabrería fue excluída del análisis). Los números y símbolos corresponden a aquellos de la Fig. 2. 


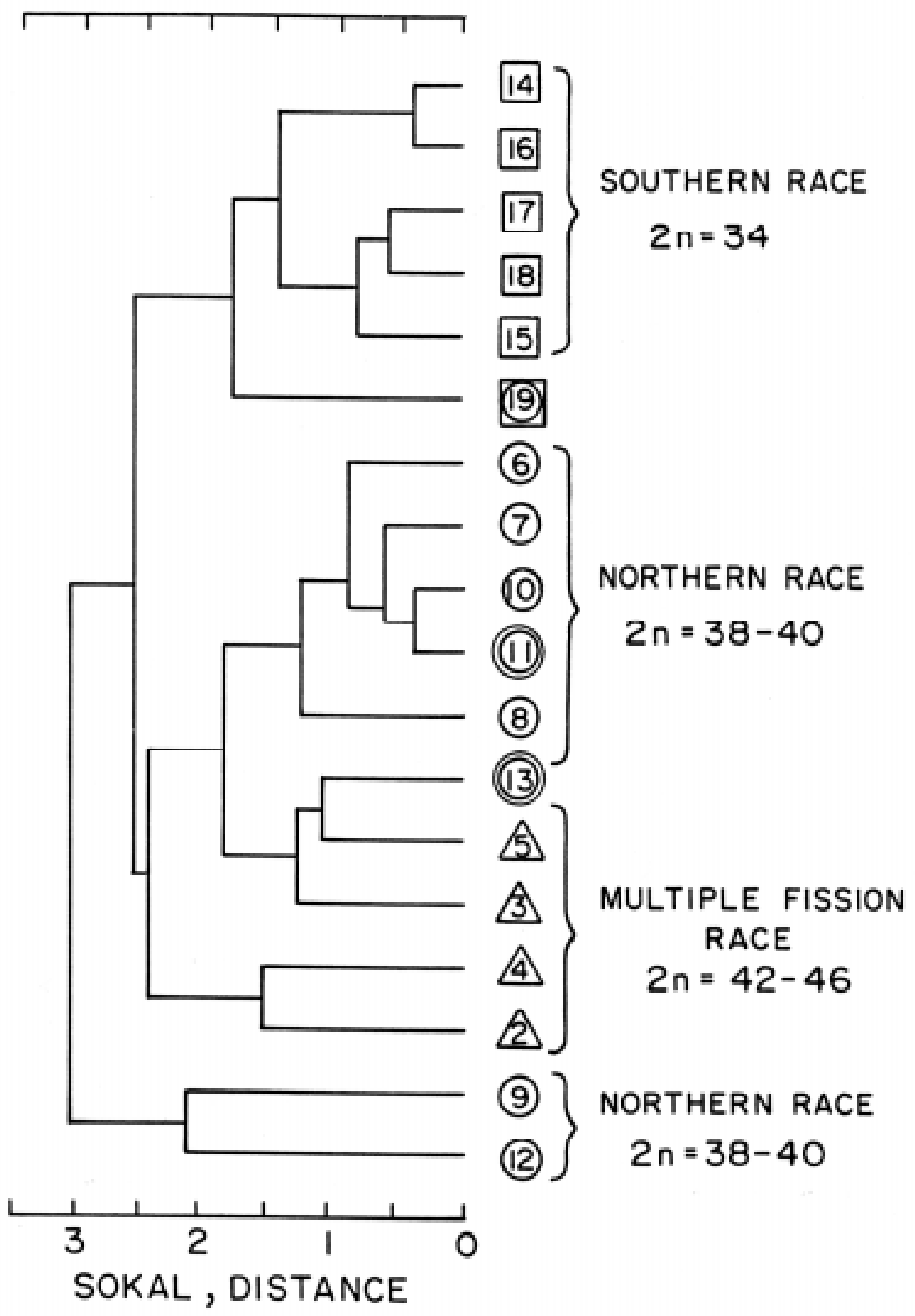

Fig. 4: Sokal's distance phenogram resulting from UPGMA clustering of the first two principal components of 29 meristic characters measured in 18 samples of Liolaemus monticola from the middle Chile. Numbers at the ends of branches correspond to the sampling localities. The symbols correspond to the chromosomal races.

Fenograma basado en distancias fenéticas de Sokal obtenido por análisis de Cluster UPGMA, para los dos primeros componentes principales de 29 caractéres merísticos medidos en 18 poblaciones de Liolaemus monticola de Chile central. Los números en cada rama terminal corresponden a las localidades muestreadas. Los símbolos corresponden a aquellos de las razas cromosómicas. 


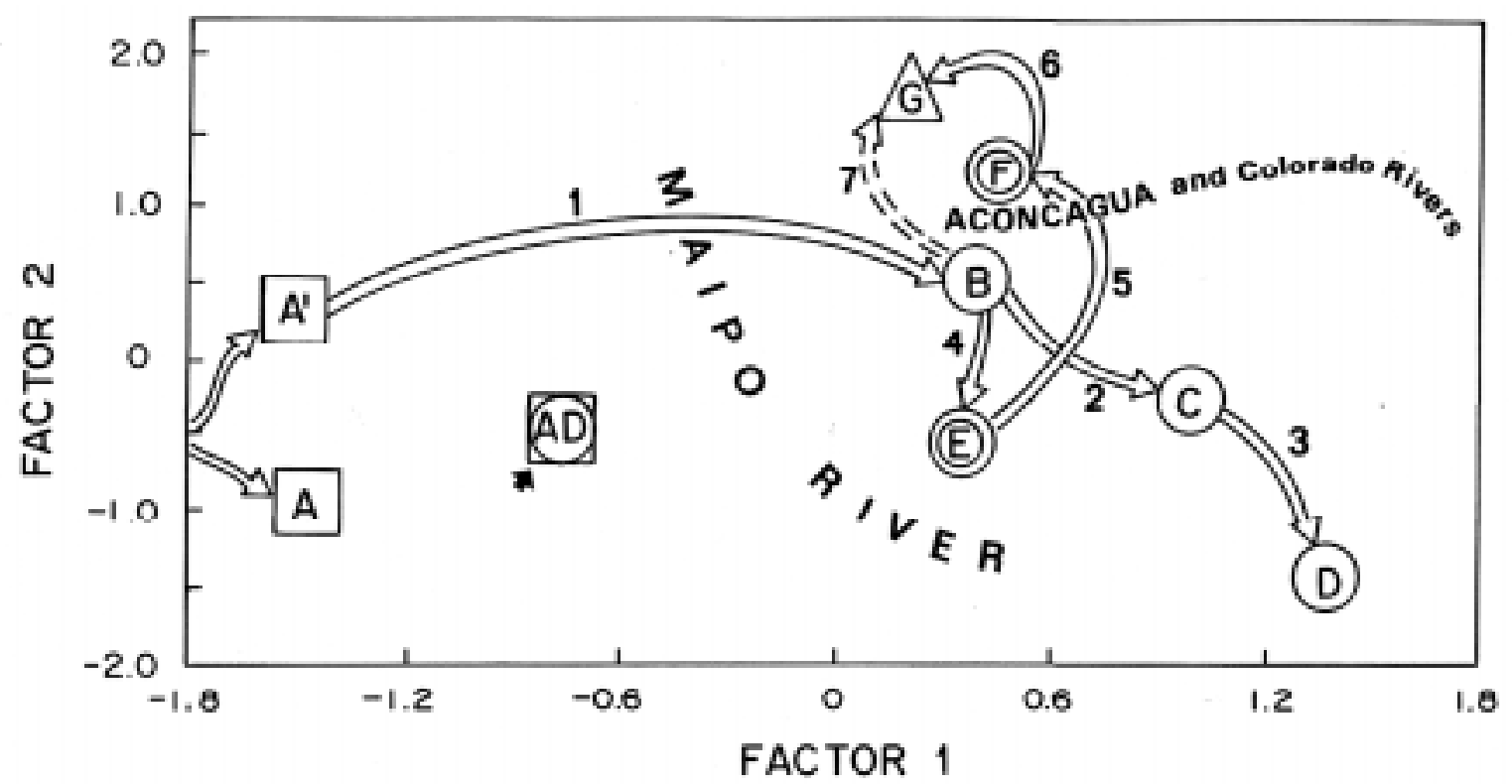

Fig. 5: Possible routes of migration and colonization (in solid lines plus arrow) of the Liolaemus monticola chromosomal races in central Chile, based on the graph of the first two principal components produced using scale count characters of nine population samples of L. monticola males plus females from central Chile. Route 1: $\mathrm{A}=$ "Southern, $2 \mathrm{n}=34$ " race (samples $15+16+17+18)$ from the Andes; $\mathrm{A}$ ' = from the Coast (sample 14) to $\mathrm{B}=$ "Northern, $2 \mathrm{n}=38-40$ " race (samples $6+7+10$ ). Route 2 : $\mathrm{B}$ to $\mathrm{C}=$ "Northern race" (sample 8). Route 3: C to D = "Northern race" Andean Range (samples 9+12). Route 4: $\mathrm{B}$ to $\mathrm{E}=$ "Northern modified 1, 2n=38-40", race (sample 11). Route 5: $\mathrm{E}$ to $\mathrm{F}=$ "Northern modified 1, $2 \mathrm{n}=38-40$ " race (sample 13). Route 6: $\mathrm{F}$ to $\mathrm{G}=$ "Multiple Fission, $2 \mathrm{n}=42-44$ " race (samples $2+3+4+5$ ). Route 7: $\mathrm{B}$ to $\mathrm{G}$ in dotted lines and arrow. $\mathrm{AD}=$ Zone of secondary contact of the "Southern" and "Northern" chromosomal races. Symbols correspond to the chromosomal races in Fig.1.

Posibles rutas de migración y colonización (en trazos sólidos, más flecha) para las razas cromosómicas de Liolaemus monticola en Chile central, basado en los gráficos de los primeros dos componentes principales producido por el conteo de escamas en 28 caracteres en nueve muestras poblacionales de machos más hembras de L. monticola agrupadas de acuerdo a la raza cromosómica o al ecotipo en Chile central. Ruta 1: A = raza "Sur, 2n=34" (muestras 15+16+17+18) de Los Andes; $\mathrm{A}^{\prime}$ = raza "Sur, 2n=34" de la cordillera de La Costa (muestra 14) a B = raza "Norte, 2n=38-40" (muestras 6+7+10). Ruta 2: de B a C = raza "Norte" (muestra 8). Ruta 3: de C a D = raza "Norte" de la cordillera de Los Andes (muestras 9+12). Ruta 4: de $\mathrm{B}$ a $\mathrm{E}=$ raza "Norte modificada $1,2 \mathrm{n}=38-40$ " (muestra 11). Ruta 5: de E a $\mathrm{F}=$ raza "Norte modificada 1, 2n=38-40" (muestra 13 ). Ruta 6: de F a G = raza "Múltiples Fisiones, 2n = 42-44" (muestras 2+3+4+5). Ruta 7: de B a G en líneas discontinuas y flecha. $\mathrm{AD}=$ zona de contacto secundario entre las razas cromosómicas "Sur" y "Norte". Los símbolos corresponden a las razas cromosómicas de la Fig. 1.

the first three factors generally grouped populations according to chromosome race (Fig. 4 ), and separates the "Southern, $2 \mathrm{n}=34$ " and the "Northern, 2n=38-40" plus the" MF, 2n=42-44". One exception is sample $\mathrm{N}^{\circ} 13$ (Río Colorado Norte) which clusters with those of the Multiple Fission race, and two samples of the Northern race (Yeso Norte and San Gabriel) that appear the most different. While the separation of the races is evident, the results are not completely satisfying, as the algorithm used cannot show the position of intermediate populations.

Based upon the results of factor analysis, we combined data for populations of the same chromosomal race which were geographical neighbors and had similar values for the first two factors: the "Southern" race Cantillana from the coast; Yeso Sur (a zone of secondary hybridization); San Gabriel plus Yeso Norte because they are different from the other "Northern" race samples; Cuesta Chacabuco from the Transverse Range; Colorado Norte and Colorado Sur from the Andes. We included APOR and used both males and female in order to have 28 characters and nine groups (Fig. 5).

Relative variability for all characters for each sample for males and females separately or for males plus females were somewhat contradictory, the greatest values were Cantillana (14) and Los Queñes (15), both belonging to the "Southern, 
$2 \mathrm{n}=34$ " race and the lowest values in San Gabriel (12) and Yeso Norte (9) from the "Northern, $2 n=38-40$ " race just north of the Maipo River and the Yeso River; however the differences were not significant using a randomization test (results not shown). Thus except for these samples, there is no indication that the derived races have less morphological variability than the ancestral chromosome race. Average values of coefficients of variation also gave non-significant results (results not shown).

\section{DISCUSSION}

In previous papers, Lamborot \& Eaton (1992, 1997) demonstrated that the morphological similarities of the Liolaemus monticola populations determined by multivariate analysis coincide exactly with the separation into "Northern, $2 \mathrm{n}=38-40 "$ and "Southern, $2 \mathrm{n}=34$ " races, and thus confirm the interpretation of the Maipo River and Yeso River as riverine barriers to gene flow. The present study included some of the samples previously analyzed, and added eight new population samples, three of the "Northern, $2 \mathrm{n}=38-40$ " race and five of the "Multiple Fission, 2n=42-44" race. The first factor of the present factor analysis has significant loadings for 10 of the same characters used in previous papers, and for six of the additional characters included in this study. This confirms that differences in a number of correlated scale characters characterize the "Southern, $2 n=34$ " race.

By introducing populations of the "MF" race and new localities of the "Northern" race such as Saladillo, Colorado Sur and Colorado Norte, it was possible to demonstrate by multivariate analyses that the Aconcagua River is also a biogeographical barrier, that separates the "Northern, $2 \mathrm{n}=38-40$ " race from the "MF, $2 \mathrm{n}=42-44$ " race. Notice that it is the first multivariate factor (Fig. 2) which highlights the morphological differences north and south of the Maipo River, while the second and third factor, although based on fewer scale characters, clearly distinguishes the "Multiple Fission" race north of the Aconcagua River.

Our analysis of scale characters of L. monticola revealed morphological and latitudinal differentiation between the three chromosomal races: "Southern, $2 \mathrm{n}=34$ ", "Northern, $2 \mathrm{n}=38-40$ " and "Multiple Fission, $2 \mathrm{n}=42-44$ " races.

These results provide evidence that both rivers have been important in chromosomal and morphological differentiation by interrupting gene flow, and by limiting the re-expansion of spatially disjunct differentiates. Also, the Maipo River appears as a stronger (or older) barrier than the
Aconcagua River for the L. monticola, since there are greater differences in more meristic characters in the former case.

Since the multivariate factors are independent, this indicates that the differentiation which resulted after crossing a river barrier has been independent in the two cases. The greater degree of differences associated with the Maipo River argues that this barrier was crossed first, in other words that this species was gradually expanding to the north.

There is no apparent tendency for the northern derived races to be less variable than the (ancestral) "Southern" race, as might be expected if the geographic barrier had been crossed fairly recently by few individuals (Hall 1973). Individual characters may be more or less variable in the North. The two least variable populations are San Gabriel and Yeso Norte, both from the "Northern" race in the Andes. If these were recently derived from nearby populations on the other side of the Maipo (and Yeso) rivers, we would expect this to be reflected in greater morphological similarity with these populations, while in fact they are quite different, except for a local hybrid zone described previously (Lamborot \& Eaton 1992). The increased variability found in Yeso Sur is due in part to the presence of a few hybrids, and although not all individuals from this population were karyotyped, this population must have received secondary contact from the hybrid zone. This aspect is being analysed through molecular markers.

The meristic characteristics of the Los Queñes population (15) are very similar to the other "Southern, $2 \mathrm{n}=34$ " race samples, although the former population is $200 \mathrm{~km}$ farther south. This suggests that the geographical distribution of this race is probably more continuous in the Andes, in spite of the fact that presently several important rivers separate Los Queñes from the other "Southern, $2 \mathrm{n}=34$ " race populations.

The present pattern of L. monticola morphological and chromosomal variability must be due to past population expansions and contractions, as imposed by geography and past environmental conditions. Once a new favorable chromosomal variant appears, it must spread and perhaps replace the old form, which could occur by natural selection, genetic drift or genetic biasing mechanisms such as meiotic drive. The hypothesized range expansion of the "Southern, $2 n=34$ " race in a northerly direction has apparently resulted in different degrees of phenotypic divergence in the Coastal Range (Cantillana) compared to the Andes, and perhaps in greater sexual dimorphism (Lamborot \& Eaton 1997). 


\section{Origin of the chromosomal races}

Since actually, and based on cytogenetic studies (Lamborot 1993, 2001), we do not have evidence for chromosome introgression from one race into the next, (except in the narrow hybrid zones) and because the chromosomal evolution has probably occurred via successive chromosomal rearrangements, producing a linear series of chromosomal races, whose complexity increases south to north and based upon previous results (Lamborot \& Eaton 1997, Lamborot 2001), we suggested that the "Northern, $2 \mathrm{n}=38-40$ " race originated from the "Southern, $2 \mathrm{n}=34$ " race in the Coastal Range, crossed to the Andes using the Transversal Range (sample 8 or C) as a bridge, and only later reached the Andes north of the Maipo River (Fig. 4). This would explain the greater morphological differences between the races in the Andes ( $=$ San Gabriel and Yeso Norte) that are separated by the Maipo River in $200 \mathrm{~m}$. South of the Maipo River and south of the Yeso River, all the L. monticola populations have $2 \mathrm{n}<34$ chromosomes, while north of the river, all populations have $2 \mathrm{n} \geq 38$ chromosomes, which suggests that the "Northern, $2 \mathrm{n}=38-40$ " race was either produced in the founding population, or once produced, it replaced the other "Southern, $2 n=34$ " race populations north of the Maipo River.

The Aconcagua River is also a biogeographical barrier that separates the "Northern, $2 \mathrm{n}=38-40$ " race from the "Multiple Fision" race. Later, the "Multiple Fision" race (G) originated from the "Northern" race. Some of the chromosomal changes may have occurred in the Andes, because samples from north and south of the Colorado River, one of the tributaries of the Aconcagua River, present intermediate morphological values between these races and appear to be intermediate in our preliminary chromosomal survey; they are polymorphic for a pericentric inversion and an enlarged chromosome, two of the five rearrangements which are present in the "Multiple Fision" race (Lamborot 1998, M. Lamborot unpublished data). Also the Colorado River appears to separate the samples from Colorado Norte (F) and Colorado Sur (E), the former being more closely related in morphology and geographic proximity to the "Multiple Fision" race. According to our hypothesis, the Colorado River samples should represent transition populations, rather than a zone of secondary contact. In fact our preliminary chromosome survey indicates that both population samples of the Colorado River correspond to a new chromosomal race with the same diploid number of those from the "Northern, $2 n=38-40$ " race, but with two out of five new chromosomal mutations that are present in those of the "Multiple Fission, $2 n=42-44$ " race. We plan to use more sensitive molecular genetic markers to provide further evidence for the proposed scheme. The greater degree of differences associated with the Maipo River and the sequence of chromosomal changes argues that this barrier was crossed first, in other words that this species was gradually expanding to the north. What is more remarkable is that in each case, the crossing of a river barrier has been accompanied by chromosomal changes in the founding population or in a new population which then replaced the older one. These results provide evidence that both rivers have been important in the chromosomal and morphological differentiation by interrupting gene flow, and by limiting the reexpansion of spatially disjunct differentiates. We hypothesize that the other new polymorphic fissions that characterize the "Multiple Fision" race (Lamborot 1998) could have arisen in the Coast Range in a similar way as the origin of the "Northern" race that escaped the glacial action.

The association between chromosomalmorphological races and river barriers may be explained in part by historical factors. Geological data for this region demonstrate that Pleistocene glaciation was extensive. In the next-to-last episode, the glacier of the Maipo Valley was particularly well developed (Brüggen 1950, Vuilleumier 1971). In the Aconcagua Valley, Caviedes (1972) considers that similar phenomena occurred, the three major Quaternary glaciations are represented in this river system and possibly a fourth glaciation which reached $1.100 \mathrm{~m}$, in the deep valley of the Colorado River. The middle course of the Aconcagua River crosses intermontane basins and cuts though the ridges of the Coastal Range. The chronology accepted by Caviedes (1972), allows the presumption that the glaciations of the middle Chilean Andes occurred "in phase" with those of the Northern Hemisphere, but never reached a similar intensity. Morraines are found in the central valley and on the eastern slopes of the Coastal Range, but not on the western slopes of the latter (Formas 1979). However, Heusser (1966) indicated that the Coast Range escaped the action of glaciers, from which we conclude that glacial tongues may well have acted as greater barriers for L. monticola in the Andes than in the Coastal Range for both the Maipo and the Aconcagua rivers.

Summarizing, our results provide evidence that the Aconcagua River $\left(32^{\circ} 52^{\prime} \mathrm{S}\right)$ as well as the Maipo and Yeso rivers $\left(33^{\circ} 46^{\prime} \mathrm{S}\right)$ have been important in the differentiation of populations of L. monticola. This is a good example of parapatric differentiation (Pounds \& Jackson 1981) produced by riverine barriers. Both rivers present similar 
Pleistocenic historical events (Brüggen 1950, Caviedes 1972).

These rivers have acted as barrier more strongly near the headwaters of the Aconcagua River than its mouth, the former represented by the Colorado River samples. We don't know if the other chromosome fission polymorphism mutations of the "Multiple Fission" race were originated from the "Northern" race at the Coastal Range and then hybridized (Fig. 4). These hypotheses should be further analyzed utilizing more sensitive (genetic) markers such as allozymes or mtDNA, in order to evaluate past patterns of gene flow.

\section{ACKNOWLEDGMENTS}

We thank Sandra Brito and Sandra Espinoza for field and Laboratory technical assistance. This work was supported by grants: FONDECYT No. 1950683 and No. 3536 of the Dirección Técnica de Investigación, Universidad de Chile.

\section{LITERATURE CITED}

BRÜGGEN J (1950) Fundamentos de la geología de Chile. Instituto Geográfico Militar, Santiago, Chile. 382 pp.

CAVIEDES C (1972) Geomorfología del Cuaternario del valle del Aconcagua, Chile central. Mi selbstverlag der Geographischen Institute der Albert-Ludwigs-Universität, Freiburg, I, Germany, Hefte No 11.153 pp.

DONOSO-BARROS R (1966) Reptiles de Chile. Ediciones de la Universidad de Chile, Santiago, Chile. 606 pp.

EATON LC (1971) Patterns of population variability in the Ranunculus occidentalis complex. Ph.D. Dissertation, Stanford University, Stanford, California. $173 \mathrm{pp}$.

FORMAS JR (1979) La herpetofauna de los bosques temperados de Sudamérica. In: Duellmann W (ed) The South American herpetofauna: its origin, evolution an dispersal: 341-369. Monograph of the Museum of Natural History N7, University of Kansas, Lawrence, Kansas.

EVANS EP, G BRECKTON \& CE FORD (1964) An airdrying method for meiotic preparations from mammalian testes. Cytogenetics 3: 289-294.

HAFFER J (1974) Avian speciation in tropical South America. Nuttall Ornithological Club Publication No. 14, Cambridge, Massachusetts. 1-390 pp.

HALL WP (1973) Comparative population cytogenetics, speciation and evolution of the crevice-using species of Sceloporus (Sauria: Iguanidae). Ph.D. Dissertation, Harvard University, Cambridge, Massachusetts. 215 pp.

HEUSSER CJ (1966) Late-Pleistocene pollen diagrams from the Province of Llanquihue, southern Chile. Proceedings of the American Philosophy Society 110: 269-305.

LAMBOROT M (1991) Karyotypic variation among populations of Liolaemus monticola (Tropiduridae), separated by riverine barriers at the Andes range. Copeia 1991: 1044-1059.
LAMBOROT M (1993) Chromosomal evolution and speciation in some Chilean lizards. Evolución Biológica 7: 133-151.

LAMBOROT M (1998) A new and highly polymorphic chromosomal race of Liolaemus monticola (Iguanidae) from the "Norte Chico" of Chile. Chromosome Research 6: 247-254.

LAMBOROT M (2001) Karyotypic polymorphism and evolution within and between the Liolaemus monticola (Iguanidae) "northern $2 \mathrm{n}=38-40$ " chromosome race populations in central Chile. Revista Chilena de Historia Natural 74: 121-138.

LAMBOROT M \& LC EATON (1992) Concordance of morphological variation and chromosomal races in Liolaemus monticola (Tropiduridae) separated by riverine barriers in the Andes. Zeitschrift für Zoologische Systematik und Evolutionsforschung 30: 189- 200.

LAMBOROT M \& E ÁLVAREZ-SARRET (1993) Karyotypic variation within and between populations of Liolaemus monticola (Tropiduridae) separated by the Maipo River in the coastal range of central Chile. Herpetologica 49: 435-449.

LAMBOROT M \& LC EATON (1997) The Maipo River as a biogeographical barrier to Liolaemus monticola (Tropiduridae) in the mountain ranges of central Chile. Journal of Zoology, Systematics and Evolution Research 35: 105-111.

LAMBOROT M, A ESPINOZA \& E ÁLVAREZ (1979) Karyotypic variation in Chilean lizards of the genus Liolaemus (Iguanidae). Experientia 35: 593-594.

LAMBOROT M, E ÁLVAREZ, I CAMPOS \& A ESPINOZA (1981) Karyotypic characterization of three Chilean subspecies of Liolaemus monticola. Journal of Heredity 72: 328-334.

MAYR E (1963) Animal species and evolution. Belknap Press of Harvard University Press, Cambridge, Massachusetts. 808 pp.

PATTON J, MN DA SILVA \& JR MALCOLM (1994) Gene genealogy and differentiation among arboreal spiny rats (Rodentia: Echimyidae) of the Amazon basin: a test of the riverine barrier hypothesis. Evolution 48: 1314-1323.

PETERS IA \& R DONOSO-BARROS (1970) Catalogue of Neotropical Squamata: Part II.Lizards and amphibians. Bulletin of the United States National Museum 297: 170-195.

POUNDS JA \& JF JACKSON (1981) Riverine barriers to gene flow and differentiation of fence lizard populations. Evolution 35: 516-528.

SITES JW Jr (1982) Morphological variation within and among three chromosome races of Sceloporus grammicus (Sauria: Iguanidae) in the north-central part of its range. Copeia 1982: 435-449.

SNEATH PH \& RR SOKAL (1973) Numerical taxonomy: principles and practice. Freeman Press, San Francisco, California. 573 pp.

SOKAL RR \& PH SNEATH (1995) Biometry. Third edition. Freeman Press, San Francisco, California. 889 pp.

VON MÜLLER L \& W HELMICH (1932) Beitrag zur Kenntnis der Herpetofauna Chiles. IV. Liolaemus monticola, ein weiterer neurer Rassenkreis aus den Hochanden Chiles. Zoologischer Anzeiger 99: 177-192.

VUILLEUMIER BS (1971) Pleistocene changes in the fauna and flora of South America. Science 173: 771-780. 